\title{
Menentukan Waktu Penggantian Komponen Dalam Mesin Bottomer Di PT Industri Kemasan Semen Gresik Menggunakan Power Law
}

\author{
Miftahul Innayahtul Hakima, Wiwiek Setya Winahju, dan Diaz Fitria Aksioma \\ Departemen Statistika, Fakultas Matematika, Komputasi, dan Sains Data, \\ Institut Teknologi Sepuluh Nopember (ITS) \\ e-mail:diaz_fa@statistika.its.ac.id
}

\begin{abstract}
Abstrak-PT. IKSG merupakan perusahaan yang memproduksi kemasan semen. Terdapat dua mesin yang digunakan untuk menghasilkan kemasan yaitu mesin Tuber dan Bottomer. Mesin yang sering mengalami kerusakan adalah mesin Botto-mer, penelitian berfokus pada komponen dalam mesin Bottomer. Tujuan dari penelitian adalah menghitung waktu optimasi peng-gantian komponen dalam mesin Bottomer menggunakan power law process (PLP), sehingga bisa meminimumkan biaya yang timbul akibat kerusakan. Hasil analisis dilakukan pengecekan setelah kerusakan pertama atau mesin sudah beroperasi selama 20 hari dengan estimasi biaya sebesar Rp78.468,952/hari. Peng-gantian komponen Bearing dilakukan setelah 2 kali pengecekan dengan MTTF (Mean Time to Failure) 48 hari. Komponen sela-in Bearing dilakukan penggantian komponen setelah melakukan 6 kali pengecekan dengan MTTF 128 hari.
\end{abstract}

Kata Kunci-Komponen dalam Mesin Bottomer, MTTF, Life Time, PLP.

\section{PENDAHULUAN}

A DANYA perbaikan pada komponen yang mengalami keru-sakan tidak selamanya efisien. Jika komponen yang ru-sak telah mengalami perbaikan beberapa kali, maka reliabili-tas dari komponen tersebut akan semakin menurun dan laju kerusakannya akan semakin meningkat. Perbaikan yang dila-kukan tersebut tidak lagi menjadi ekonomis dan perusahaan akan mengeluarkan biaya yang lebih besar dalam perbaikan komponen yang mengalami kerusakan, sehingga komponen yang rusak akan dibuang dan diganti yang baru [1]. Menen-tukan waktu penggantian mesin membutuhkan perhitungan yang tepat menggunakan replacement model. Replacement model digunakan untuk menentukan waktu komponen atau mesin diberikan penggantian secara berkala setelah periode ke $T$ atau kerusakan ke $N$ setelah instalasi, tergantung mana yang lebih dulu terjadi [2].

PT. Industri Kemasan Semen Gresik (IKSG) merupakan anak perusahaan PT. Semen Indonesia (Persero) Tbk dengan bidang usaha pembuatan kemasan industri. Proses produksi dibedakan menjadi dua yaitu proses produksi kemasan jahit dan kemasan lem. Nama produk yang dihasilkan dari proses kemasan jahit adalah Sewn (Kemasan Kraft Jahit) dan nama produk untuk kemasan lem adalah Pasted Kraft (Kemasan Kraft Lem) dan Pasted Woven (Kemasan Woven Lem). Terdapat enam line yang digunakan untuk produksi dimana setiap line mempunyai dua mesin yang digunakan yaitu mesin Tuber dan Bottomer. Mesin yang sering mengalami kerusakan adalah mesin Bottomer diline satu. Mesin Bottomer mempunyai dua bagian komponen yaitu komponen bagian dalam dan komponen bagian luar mesin. Komponen ba- gian dalam mesin terdiri dari Bearing, Spring, Pin, Gear, dan Baut. Bagian luar mesin terdiri dari Flat Belt, Timing Belt, Transporter Belt, Shaft, Pulley, dan lain-lain. Pemeliharaan mesin di PT. IKSG adalah dengan melakukan overhoul dan melakukan pengecekan komponen sebelum mesin berproduksi setelah tidak beroperasi. Line yang dilakukan overhoul adalah line yang mempunyai permintaan tinggi dari konsumen. Mesin yang mengalami kerusakan akan membuat produk yang dihasilkan menjadi produk cacat. Cacat pada produk yang sering terjadi diakibatkan oleh lem yang tidak bisa merekat dengan baik, hal tersebut dikarenakan kerusakan komponen dalam mesin. Kerusakan yang terjadi disebabkan perbaikan dan penggantian komponen yang tidak terjadwal, sehingga penelitian yang dilakukan berfokus pada komponen bagian dalam mesin.

Menentukan waktu yang tepat dalam melakukan penggantian komponen bagian dalam Bottomer, sehingga biaya yang dikeluarkan akibat kerusakan menjadi minimum menggunakan metode PLP. PLP atau model Weibull Process adalah salah satu model yang digunakan untuk data yang mengikuti Non-Homogeneous Poisson Process dengan distribusi Weibull. Non-Homogeneous Poisson Process (NHPP) disebut dengan Weibull Process karena Rate of Occurance of Failure (ROCOF) memiliki fungsi failure rate yang sama dengan distribusi Weibull. Non-Homogeneous Poisson Process (NHPP) merupakan proses poisson dengan laju kerusakan tidak konstan [3]. Batasan pada penelitian ini adalah data life time yang digunakan hanya komponen bagian dalam mesin Bottomer. Diasumsikan komponen bagian dalam mesin Bottomer setelah pemeliharaan mempunyai kinerja seperti terakhir sebelum terjadi kerusakan, serta faktor kerusakan pada mesin Bottomer hanya disebabkan oleh life time dari komponen dalam mesin.

Penelitian sebelumnya yang menggunakan metode Power Law Process dengan komponen yang digunakan adalah komponen Heat Exchanger (HE), memberikan kesimpulan bahwa tindakan perbaikan terhadap komponen Heat Exchanger (HE) sebaiknya dilakukan pada saat komponen telah beroperasi selama 8900 flight hours atau ketika terjadi kerusakan pertama sebelum mencapai waktu operasi 8900 flight hours dengan estimasi biaya yang minimum sebesar 0,1090 per flight hours [4]. Penelitian lain yang menggunakan metode Power Law Process dengan melakukan analisis pada dua mesin yaitu mesin HSB Kazo dan HSB By AB pada komponen Impeler. Memberikan kesimpulan bahwa waktu penggantian yang tepat untuk Impeler mesin HSB Kaza adalah komponen sudah beroperasi selama 601 jam dengan biaya minimum sebesar Rp 93.665,99/jam. Komponen Impeler mesin HSB $B y A B$ akan diganti setelah beroperasi selama 
634 jam dengan biaya minimum sebesar Rp 88.881,61/jam [5].

\section{TINJAUAN PUSTAKA}

\section{A. Stochastic Process}

Jumlah kerusakan sebesar $N$, dimana $N$ adalah variabel random pada interval waktu $(0, t)$. Proses dari $\{N, t \geq 0\}$ disebut dengan stochastic process yang memiliki realisasi berupa counting process, yang digunakan untuk mengetahui hubungan dari suatu runtutan peristiwa atau proses kejadian yang bersifat tidak pasti. Proses yang timbul dari pengembangan stochastic prosess dan penelitian tentang strategi penggantian komponen adalah Renewal Process dana Minimal Repair [6]. Dikatakan Renewal Process jika sistem atau komponen rusak akan dilakukan pengembalian kepada kondisi seperti komponen baru (as good as new) setelah dilakukan perbaikan. Terdapat dua jenis sistem yaitu repairable dan non-repairable system, repairable system yaitu sebuah sistem dimana ketika terjadi sebuah kerusakan sistem tersebut dapat diperbaiki dengan beberapa proses perbaikan selain penggantian pada seluruh sistem. Non-repairable system adalah suatu sistem jika mengalami kerusakan harus diganti dengan sistem baru [3].

Minimal repair merupakan sistem yang gagal akan berfungsi kembali setelah perbaikan dilakukan dengan kondisi sama dan usia efektif sama seperti pada saat kerusakan terakhir. Minimal repair mengasumsikan waktu perbaikan dianggap sangat minimum dan untuk memperoleh model yang fleksibel dari suatu sistem kerusakan yang akan diperbaiki dalam minimal repair, maka hanya sebagian kecil proporsi dari unsur-unsur sistem akan diganti pada proses repair. Hal ini akan mengondisikan sistem sama seperti sebelum sistem mengalami kerusakan [3].

\section{B. Power Law Process (PLP)}

PLP atau proses Weibull meruapakan suatu model yang digunakan untuk mengecek data yang mengikuti NonHomogeneus Poisson Processes (NHPP). NHPP adalah proses poisson dengan laju kerusakan yang tidak konstan. Rate of Occurance of Failure (ROCOF) NHPP mempunyai failure rate sama dengan distribusi Weibull. ROCOF adalah estimasi nilai laju kerusakan dari suatu komponen [3]. Distribusi Weibull mempunyai fungsi reliabilitas yang dijelaskan sebagai berikut.

$$
S(t)=\exp \left[-\left(\frac{t}{\theta}\right)^{\beta}\right], t>0
$$

$t$ merupakan variabel random dengan fungsi distribusi kumulatif seperti pada persamaan 2 .

$$
F(t)=1-S(t)=1-\exp \left[-\left(\frac{t}{\theta}\right)^{\beta}\right], t>0
$$

sehingga didapatkan fungsi kepadatan peluang, laju kerusakan, dan Mean Time to Failure (MTTF) sebagai berikut.

$$
f(t)=F^{\prime}(t)=\frac{\beta}{\theta}\left(\frac{t}{\theta}\right)^{\beta-1} \exp \left[-\left(\frac{t}{\theta}\right)^{\beta}\right]
$$

$$
\begin{gathered}
\lambda(t)=\frac{f(t)}{S(t)}=\frac{\frac{\beta}{\theta}\left(\frac{t}{\theta}\right)^{\beta-1} \exp \left[-\left(\frac{t}{\theta}\right)^{\beta}\right]}{\exp \left[-\left(\frac{t}{\theta}\right)^{\beta}\right]}=\frac{\beta}{\theta}\left(\frac{t}{\theta}\right)^{\beta-1} \\
M T T F=\theta \Gamma\left(1+\frac{1}{\beta}\right)
\end{gathered}
$$

dimana $\theta$ adalah parameter scale dan $\beta$ adalah parameter shape [6].

\section{Time Truncated Case dan Time Failure Truncated Case}

Data dikatakan menjadi time truncated case bila pengamatan berhenti setelah ditentukan waktu $t$. Pengamatan sistem sampai waktu $t$, menghasilkan jumlah kerusakan sebesar $N$ dimana $N$ adalah variabel random. Laju kerusakan NHPP adalah $\lambda(t)$ dengan pengamatan sampai waktu $t$ dan waktu kerusakan $T_{1}<T_{2}<\ldots<T_{N}$ dimana $N$ adalah jumlah kerusakan dalam interval $(0, t)$. Bila suatu pengamatan berhenti setelah ditentukan jumlah kerusakan, maka data dikatakan failure truncated case dengan waktu kerusakan $T_{1}<T_{2}<\ldots<T_{n}$. Pengamatan kerusakan komponen menggunakan time truncated case maka $t$ merupakan fixed variabel dan $N$ merupakan variabel random. Sedangkan pengamatan sistem yang menggunakan failure truncated case mempunyai nilai $t$ sebagai variabel random dan $N$ sebagai fixed $v a-$ riabel [3].

\section{Pengujian Trend}

Peningkatan rate of failure pada sistem mengindikasikan bahwa komponen dalam keadaan yang tidak baik dimana rate of failure menunjukkan life time suatu mesin. Langkah selanjutnya adalah melakukan analisis data dengan pengujian statistik untuk mengetahui apakah rate of failure mengalami kenaikan. Berikut merupakan hipotesis yang digunakan. $\mathrm{H}_{0}$ : Rate of failure tidak mengalami trend atau mengikuti Homogeneous Poisson Process.

$\mathrm{H}_{1}$ : Rate of failure mengalami trend atau mengikuti NonHomogeneous Poisson Process.

Statistik uji menggunakan Cramer-von Mises test dengan ru-mus sebagai berikut.

$$
C_{R}^{2}=\frac{1}{12 N}+\sum_{i=1}^{N}\left(\hat{R}_{i}-\frac{2 i-1}{2 N}\right)^{2}
$$

$\hat{R}_{i}=\left(\frac{T_{i}}{t}\right)^{\bar{\beta}} \operatorname{dan} \bar{\beta}=\frac{N-1}{N} \hat{\beta}, \bar{\beta}$ merupakan estimator ti-

dak bias untuk $\beta$. Hasil dari perhitungan menggunakan Persamaan (2.6) dibandingan dengan nilai tabel $C_{R \text { tabel }(n, \alpha)}^{2}$, dimana $\mathrm{H}_{0}$ ditolak jika $C_{R}^{2}<C_{R \operatorname{tabel(n,\alpha )}}^{2}[3]$.

\section{E. Estimasi Parameter Time Truncated Case}

Nilai waktu kerusakan sebesar $T_{1}<T_{2}<\ldots<T_{N}<t$, pengamatan waktu kerusakan berhenti setelah ditetapkannya waktu $t$, sehingga kerusakan ke- $N$ adalah variabel random. Time truncated case harus mempertimbangkan keacakan dari $N$ dan keacakan dari waktu kerusakan $t_{1}<t_{2}<\ldots<t_{N}$. Persamaan likelihood untuk time truncated dapat diturunkan sebagai peluang bersama dari $\left(N, T_{1}, \ldots, T_{N}\right)$ [3]. 


$$
f\left(n, t_{1}, \ldots t_{n}\right)=\left\{\begin{array}{l}
f_{N}(n) f\left(t_{1}, \ldots t_{n} \mid n\right), n \geq 1 \\
f_{N}(0), \quad n=0
\end{array}\right.
$$

$N$ merupakan variabel random yang mengikuti distribusi Poisson dengan mean $\left(\frac{t}{\theta}\right)^{\beta}$ sehingga diberikan pada persamaan (8) yang merupakan fungsi densitas ketika kejadian rusak terjadi lebih besar sama dengan 1 adalah sebagai berikut.

$$
f_{N}(n)=\frac{\left[\left(\frac{t}{\theta}\right)^{\beta}\right]^{n} \exp \left[-\left(\frac{t}{\theta}\right)^{\beta}\right]}{n !}, n=0,1, \ldots
$$

Distribusi bersyarat dari $T_{1}<T_{2}<\ldots<T_{N}$ diberikan $N=n$, dimana variabel random $T_{1}<T_{2}<\ldots<T_{n}$ telah terdistribusi sebagai $n$ order statistik dari distribusi Weibull dengan CDF (Cumulative Density Fuction) sebagai berikut.

$$
G(y)=\left\{\begin{array}{lc}
0 & y<0 \\
\Lambda(y) / \Lambda(t) & 0 \leq y \leq t \\
1 & y>1
\end{array}\right.
$$

Sehingga untuk Power Law Process (PLP) mempunyai CDF yaitu $G(y)=\frac{(y / \theta)^{\beta}}{(t / \theta)^{\beta}}=\left(\frac{y}{t}\right)^{\beta}, 0 \leq y \leq t$. Fungsi densitas dari $G(y)$ adalah $g(y)=\frac{\beta}{t}\left(\frac{y}{t}\right)^{\beta-1}, 0 \leq y \leq t \quad$ diberikan $N=n$ dan $T_{1}<T_{2}<\ldots<T_{n}$ dengan nilai $n \geq 1$ maka, Persamaan 7 pada $t$ bersyarat $n$ mempunyai fungsi densitas yang dijelaskan sebagai berikut.

$$
\begin{aligned}
f\left(t_{1}, t_{2}, \ldots t_{n} \mid n\right) & =n ! \prod_{i=1}^{n} G^{\prime}\left(t_{i}\right) \\
& =n ! \prod_{i=1}^{n} \frac{\beta}{t}\left(\frac{t_{i}}{t}\right)^{\beta-1}
\end{aligned}
$$

untuk $0<t_{1}<t_{2}<\ldots<t_{n}<t$. Peluang bersama dari $N$ dan $T_{1}<T_{2}<\ldots<T_{N}$ dinyatakan sebagai berikut.

$$
\begin{aligned}
f\left(n, t_{1}, \ldots t_{n}\right) & =\frac{\left[\left(\frac{t}{\theta}\right)^{\beta}\right]^{n} \exp \left[-\left(\frac{t}{\theta}\right)^{\beta}\right]}{n !} n ! \prod_{i=1}^{n} \frac{\beta}{t}\left(\frac{t_{i}}{t}\right)^{\beta-1} \\
& =\frac{t^{n \beta}}{\theta^{n \beta}} \frac{\beta^{n}}{t^{n}}\left[\prod_{i=1}^{n}\left(\frac{t_{i}}{t}\right)\right]^{\beta-1} \exp \left[-\left(\frac{t}{\theta}\right)^{\beta}\right] \\
& =\frac{\beta^{n}}{\theta^{n \beta}}\left[\prod_{i=1}^{n} t_{i}\right]^{\beta-1} \exp \left[-\left(\frac{t}{\theta}\right)^{\beta}\right]
\end{aligned}
$$

untuk $n \geq 1$ dan $0<t_{1}<t_{2}<\ldots<t_{n}<t$. Fungsi densitas ketika $n=0$ dinyakan sebagai barikut.

$$
f_{N}(0)=\exp \left(-\frac{t}{\theta}\right)^{\beta}
$$

Persamaan (11) dapat diubah ke dalam bentuk fungsi $\log$ likelihood dan diturunkan terhadap $\beta$ dan $\theta$, hasil estimasi parameter menggunakan MLE (Maximum Likelihood Estimation) adalah sebagai berikut.

$$
\hat{\theta}=\frac{t}{N^{\frac{1}{\hat{\beta}}}}
$$

dan

$$
\hat{\beta}=\frac{N}{\sum_{i=1}^{N} \ln \left(\frac{t}{T_{i}}\right)}
$$

\section{F. Replacement Model}

Replacement model adalah penggantian mesin atau komponen secara teratur dalam periode ke- $T$ atau pada kerusakan ke- $N$ setelah instalasi, tergantung mana yang lebih dahulu terjadi pertama kali. Mesin hanya mengalami perbaikan minimal pada kerusakan antara penggantian secara berkala, sehingga ROCOF suatu mesin tidak terganggu. Waktu yang dibutuhkan untuk perbaikan dan penggantian diasumsikan dapat diabaikan. Praktek penggantian dalam periode ke$T$ atau pada kerusakan ke- $N$, menggunakan model penggantian yang dirumuskan oleh Nakagawa dan Kowada (1983), kebijakan penggantian optimal yang berdasarkan dengan meminimumkan ekspektasi biaya jangka panjang adalah sebagai berikut

$$
c(T ; N)=\frac{c_{f}\left[N-\sum_{i=0}^{N-1}(N-i) \frac{[\Lambda(T)]^{i}}{i !} e^{-\Lambda(T)}\right]+c_{p}}{\sum_{i=0}^{N-1} \int_{0}^{T} \frac{[\Lambda(t)]^{i}}{i !} e^{-\Lambda(t)} d t}
$$

dimana $T>0, N=1,2, \ldots$ dengan nilai $c_{f}$ adalah cost of failure dan $c_{p}$ adalah cost of preventive. Kebijakan penggantian yang optimal untuk setiap jenis komponen ditentukan dengan meminimalkan persamaan $c(T ; N)$ yang berhubungan dengan nilai $T$ dan $N$ [2]. Laju kerusakan Power Law Prosess (PLP) untuk waktu kerusakan Non-Homogeneous Poisson Process dinyatakan dalam Persamaan (16) sebagai berikut.

$$
\Lambda(t)=\int_{0}^{t} \lambda(t)=\left(\frac{t}{\theta}\right)^{\beta}
$$

dimana parameter $\beta>0$ dan $\theta>0$, parameter $\beta$ menunjukkan sistem yang memburuk seiring dengan bertambahnya waktu. Jika $\beta>1$ maka laju kerusakan $\lambda(t)$ akan meningkat, sedangkan $\beta<1$ maka laju kerusakan $\lambda(\mathrm{t})$ akan menurun dan jika $\beta=1$ menunjukkan waktu kerusakan Homogeneous Poisson Process dengan fungsi intensitas $\lambda(t)=1 / \theta[3]$.

\section{G. Mesin Bottomer}

Proses produksi yang sering mengalami kendala di PT. IKSG adalah proses produksi kemasan lem. Terdapat enam line dan setiap line mempunyai dua mesin yang digunakan yaitu mesin Tuber dan Bottomer. Setiap line mempunyai jenis dan tujuan yang berbeda. Line satu, dua, dan enam memproduksi kemasan isi $40 \mathrm{~kg}$, PPC (jenis semen), Kemasan semen gresik, JTM (Pemasaran Jawa dan Bali), A (kemasan yang diproduksi di Tuban) dengan nama OP (operator), 023 (kode operator), E (kualitas kertas). Line 3 memproduksi kemasan semen Bima, line 4 untuk kemasan Semen Gresik untuk proyek, line 5 isi $50 \mathrm{~kg}$ SG. Mesin yang sering mengalami kerusakan adalah mesin Bottomer. Mesin Bottomer mempunyai konstruksi mesin yaitu rotary feeder, tube aligning unit, diagonal greasing unit, bottom opening unit, valve unit, bottom pasting unit, bottom forming unit, 
bottom turning unit, pressing and counting unit, stacking unit, press conveyor, switch conveyor.

\section{METODOLOGI PENELITIAN}

\section{A. Sumber Data}

Data yang digunakan merupakan data sekunder yang diperoleh dari bagian maintanance di PT. Industri Kemasan Semen Gresik (IKSG). Data yang digunakan berupa data life time komponen bagian dalam Mesin Bottomer diline satu mulai dari bulan Januari 2015 sampai Nopember 2017.

\section{B. Variabel Penelitian}

Variabel penelitian yang digunakan adalah data life time pada komponen bagian dalam mesin Bottomer yang ditampilkan pada Tabel 1 .

Tabel 1.

Struktur Data

\begin{tabular}{cc}
\multicolumn{2}{c}{ Struktur Data } \\
\hline \hline Kerusakan ke- $i$ & Life Time $(1065$ Hari) \\
\hline 1 & $T_{1}$ \\
2 & $T_{2}$ \\
3 & $T_{3}$ \\
$\cdot$ & $\cdot$ \\
$\cdot$ & $\cdot$ \\
$\cdot$ & $\cdot$ \\
$N$ & $T_{N}$ \\
\hline \hline
\end{tabular}

Keterangan :

$T_{1} \quad$ : Waktu kerusakan pertama pada komponen bagian dalam mesin Bottomer.

$T_{2} \quad$ : Waktu kerusakan kedua pada komponen bagian dalam mesin Bottomer.

$T_{N} \quad$ : Waktu kerusakan ke- $N$ pada komponen bagian dalam mesin Bottomer.

\section{Langkah Analisis}

Langkah analisis yang digunakan dalam menentukan optimasi waktu penggantian komponen bagian dalam mesin Bottomer adalah sebagai berikut.

1. Mengumpulkan data life time komponen bagian dalam mesin Bottomer.

2. Menetapkan time truncated case yaitu tiga tahun dari Januari 2015 sampai Nopember 2017.

3. Menguji adanya trend dalam rate of failure komponen bagian dalam mesin Bottomer dengan metode Cramer-von Mises test pada persamaan (6).

4. Menentukan estimasi parameter life time komponen bagian dalam mesin Bottomer menggunakan Persamaan (14) dan (13) dan membuat grafik ROCOF.

5. Mendapatkan model optimasi dengan penaksir parameter $\hat{\theta}$ dan $\hat{\beta}$.

a. Memperoleh fungsi $\lambda(t)$ terhadap waktu dengan menggunakan persamaan (16).

b. Menghitung $c(T ; N)$ untuk mendapatkan waktu dan biaya yang optimum menggunakan persamaan (15).

6. Menarik kesimpulan dari hasil analisis.

\section{ANALISIS DAN PEMBAHASAN}

Mesin dalam Bottomer merupakan repairable system, karena saat terjadi kerusakan mesin dilakukan proses perbaikan. Perbaikan yang dilakukan membuat mesin dalam Bottomer mempunyai kinerja sebelum terjadi kerusakan atau disebut dengan kondisi as good as new. Data life time yang digu- nakan untuk penelitian menggunakan time truncated case, dengan $T$ yang ditetapkan selama 1065 hari.

\section{A. Karakteristik Life Time Komponen Bagian dalam Mesin Bottomer}

Komponen bagian dalam mesin Bottomer mempunyai beberapa komponen yaitu Bearing, Baut, Gear, Pin, Spring, Shaft. Karakteristik life time komponen dalam mesin Bottomer dapat disajikan secara visual dengan menggambarkan plot antara banyaknya kerusakan dengan kumulatif life time komponen bagian dalam mesin Bottomer.

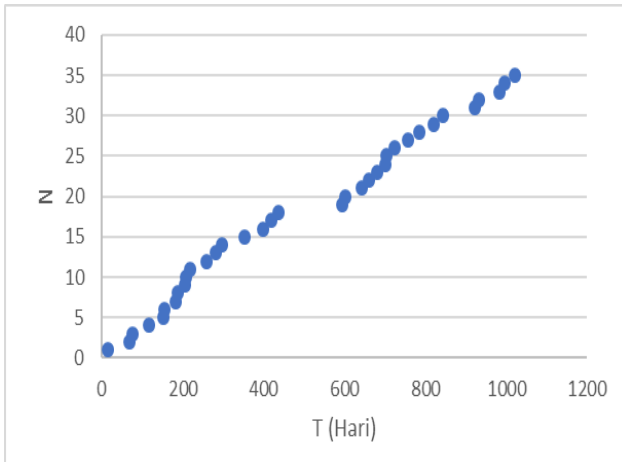

Gambar 1. Life Time Komponen dalam Mesin Bottomer.

Gambar 1 mengindikasikan bahwa life time dari komponen dalam mesin Bottomer tetap stabil, karena grafik membentuk garis linier selama tiga tahun terakhir yaitu dari tahun Januari 2015 sampai Nopember 2017.

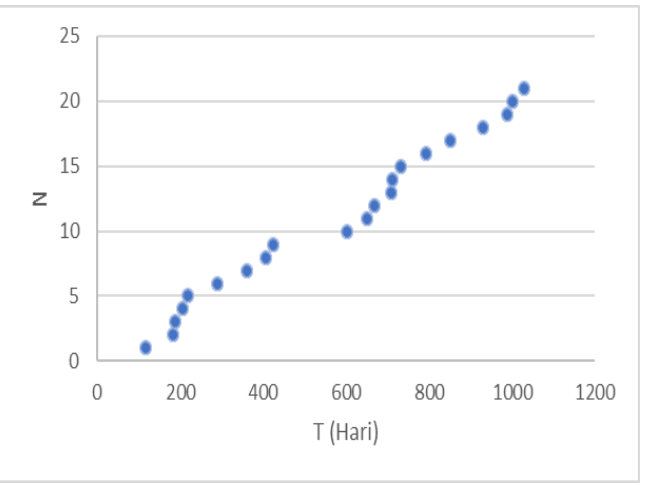

Gambar 2. Life Time Komponen Bearing.

Berdasarkan Gambar 2 life time komponen Bearing membentuk garis linier, sehingga life time komponen Bearing selama 3 tahun terakhir tetap stabil yaitu dari tahun Januari 2015 sampai Nopember 2017.

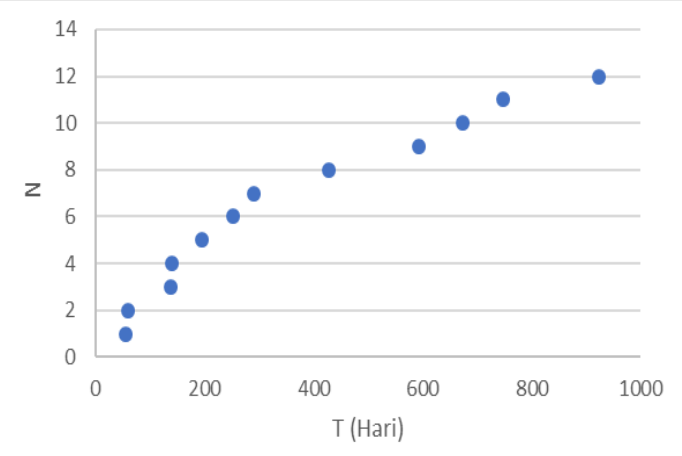

Gambar 3. Life Time Komponen Selain Bearing. 
Gambar 3 mengindikasikan terdapat peningkatan reliabilitas karena waktu antar kerusakan besar, sehingga $t$ menjadi besar. Hal tersebut ditunjukkan antar titik pada Gambar 3 semakin besar.

\section{B. Pengujian Trend pada Data Lifetime Komponen dalam Mesin Bottomer}

Pengujian trend pada data lifetime komponen dalam mesin Bottomer merupakan langkah awal untuk mengetahui, apakah data lifetime mesin Bottomer mengikuti NonHomogeneous Poisson Prosess (NHPP). Lifetime dari komponen dalam mesin Bottomer dapat diketahui dari data kerusakan mesin. Pengujian trend menggunakan metode Cramervon Mises test.

Tabel 2.

Pengujian Trend pada Kerusakan Komponen dalam Mesin Bottomer

\begin{tabular}{cccc}
\hline \hline Mesin & $\begin{array}{c}\text { Cramer-von } \\
\text { Mises }\end{array}$ & $\begin{array}{c}\text { Critical } \\
\text { Value }\end{array}$ & $\begin{array}{c}\text { Keputusa } \\
\mathrm{n}\end{array}$ \\
\hline $\begin{array}{c}\text { Bottome } \\
r\end{array}$ & 0,0477 & 0,219 & Tolak H $\mathrm{H}_{0}$ \\
\hline \hline
\end{tabular}

Hasil perhitungan yang ditampilkan pada Tabel 2 memberikan kesimpulan tolak $\mathrm{H}_{0}$ yang mempunyai arti, bahwa lifetime yang terjadi pada komponen dalam mesin Bottomer mengikuti Non-Homogeneous Poisson Process. Kesimpulan itu diambil karena nilai $C_{R}^{2}$ sebesar 0,0477 lebih kecil dari $C_{\text {Rtabel }(n, \alpha)}^{2}$ sebesar 0,219.

\section{Estimasi Parameter dan Grafik ROCOF (Rate of Occu- rance of Failure)}

Hasil perhitungan estimasi parameter didapatkan nilai parameter $\beta$ sebesar 0,935 dan paramter $\theta$ sebesar 23,762 . Parameter $\beta$ yang lebih kecil dari satu menunjukkan bahwa laju kerusakan mesin dalam Bottomer semakin menurun. Setelah mendapatkan nilai parameter, maka nilai tersebut akan digunakan untuk menghitung nilai ROCOF dari komponen dalam mesin Bottomer. Berikut adalah nilai ROCOF yang dipaparkan pada Tabel 3.

Tabel 3.

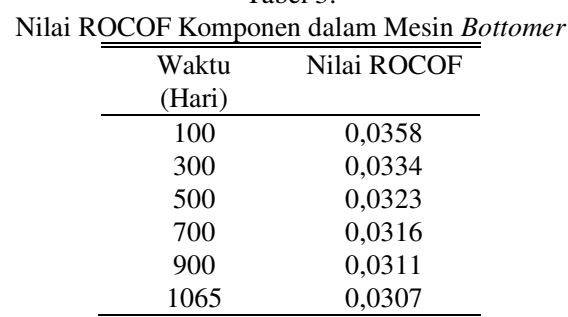

Berdasarkan Tabel 3 nilai laju kerusakan dari waktu ke waktu terus mengalami penurunan untuk komponen bagian dalam mesin Bottomer. Hal tersebut menunjukkan jika semakin kecil laju kerusakan semakin kecil kemungkinan terjadi kerusakan dalam waktu dekat. Komponen dalam mesin Bottomer. Berikut penjelasan kerusakan komponen dalam mesin Bottomer secara visual, melalui plot antara waktu kerusakan (T) dengan nilai ROCOF.

Gambar 4 menunjukkan secara detail nilai laju kerusakan komponen dalam mesin Bottomer semakin turun. Hal tersebut menunjukkan bahwa pemeliharaan yang dilakukan untuk komponen dalam mesin Bottomer sudah bagus, sehingga kondisi komponen baik untuk melakukan produksi kemasan.

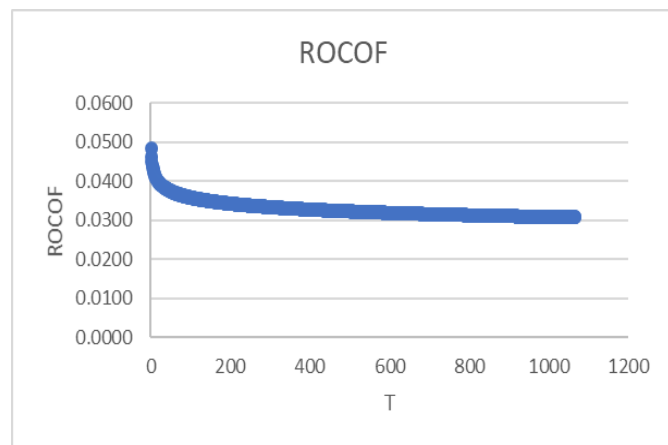

Gambar 4. Nilai ROCOF

\section{Replacement Model}

Pemeliharaan mesin yang paling diperhatikan adalah biaya yang dikeluarkan untuk proses pemeliharaan. Terdapat dua biaya yang digunakan untuk replacement model yaitu $c_{p}$ adalah biaya pemeliharaan terencana dan $c_{f}$ adalah biaya yang dikeluarkan saat mesin mengalami kerusakan. Biaya pemeliharaan terencana didapatkan dari biaya overhoul, sedangkan biaya yang dikeluarkan saat mesin rusak dari biaya penggantian komponen dan lost product saat mesin mengalami kerusakan. Komponen bagian dalam mesin Bottomer mengalami proses pemeliharaan terencana maka biaya minimal yang dikeluarkan oleh PT. IKSG sebesar Rp38.129,342/hari. Minimal biaya yang keluar saat mesin mengalami kerusakan sebesar RP 1.738.350,011/hari. Nilai $c_{p}$ dan $c_{f}$ akan digunakan untuk menghitung replacement model dengan persamaan sebagai berikut.

$$
c(T ; N)=\frac{1.738 .350,011\left[N-\sum_{i=0}^{N-1}(N-i) \frac{[\Lambda(T)]^{i}}{i !} e^{-\Lambda(T)}\right]+38.129,342}{\sum_{i=0}^{N-1} \int_{0}^{T} \frac{[\Lambda(t)]^{i}}{i !} e^{-\Lambda(t)} d t}
$$

Mendapatkan nilai minimum dari $c(T ; N)$ membutuhkan nilai parameter $\theta$ dan $\beta$ serta menentukan waktu $(T)$ dan jumlah kerusakan $(N)$. Hasil dari replacement model yang digunakan untuk mendapatkan estimasi biaya adalah sebagai berikut.

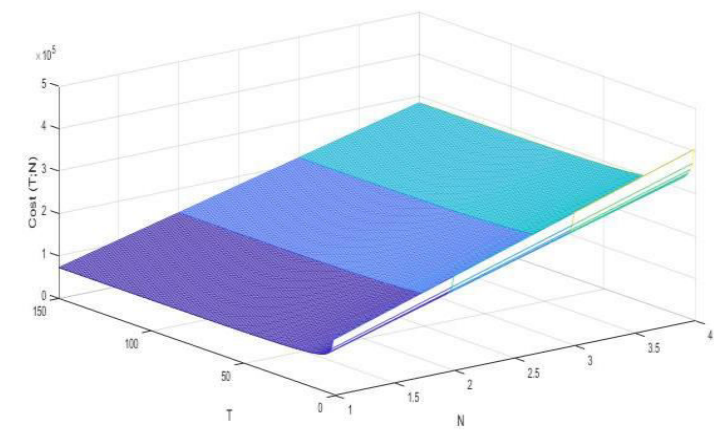

Gambar 5. Replacemenet Model Mesin Dalam Bottome.

Berdasarkan Gambar 5 estimasi biaya didapatkan dari selisih harga yang dianggap kecil dan sudah stady state. Waktu pengecekan komponen bagian dalam mesin Bottomer dilakukan sebelum 24 hari sesuai dengan perhitungan MTTF. Ekspektasi biaya pada komponen dalam mesin Bottomer dalam Tabel 4. 
Tabel 4.

Ekspektasi Biaya (Rp) Kerusakan Komponen dalam Mesin Bottomer

\begin{tabular}{ccccc}
\hline \hline Waktu & \multicolumn{4}{c}{ Kerusakan ke- } \\
\cline { 2 - 5 }$($ Hari $)$ & 1 & 2 & 3 & 4 \\
\hline 1 & 130392,80 & 221242,18 & 312091,55 & 402940,93 \\
2 & 107146,12 & 194043,19 & 280940,26 & 367837,33 \\
3 & 98496,42 & 183180,94 & 267865,45 & 352549,97 \\
4 & 93753,83 & 176915,90 & 260077,98 & 343240,05 \\
5 & 90669,45 & 172679,53 & 254689,61 & 336699,70 \\
6 & 88460,14 & 169548,96 & 250637,78 & 331726,60 \\
$:$ & $:$ & $:$ & $:$ & $:$ \\
\hline \hline
\end{tabular}

Tabel 4.

Ekspektasi Biaya (Rp) Kerusakan Komponen dalam Mesin Bottomer (Lanjutan)

\begin{tabular}{lllll}
\hline \hline 1 & \multicolumn{4}{c}{ (Lanjutan) } \\
8 & 79110,17 & 155119,12 & 231128,07 & 307137,02 \\
1 & 78776,67 & 154562,11 & 230347,55 & 306132,99 \\
9 & & & & \\
2 & 78468,95 & 154045,28 & 229621,61 & 305197,95 \\
0 & & & & \\
2 & 78183,94 & 153564,12 & 228944,30 & 304324,47 \\
1 & & & & \\
2 & 77919,07 & 153114,81 & 228310,55 & 303506,29 \\
2 & & & & \\
2 & 77672,16 & 152694,11 & 227716,05 & 302738,00 \\
3 & & & & \\
2 & 77441,37 & 152299,23 & 227157,09 & 302014,95 \\
4 & & & & \\
\hline \hline
\end{tabular}

Tabel 4 menunjukkan pemilihan waktu pengecekan komponen bagian dalam mesin Bottomer, ketika mengalami kerusakan menghasilkan biaya yang mempunyai selisih yang dianggap kecil dan sudah stady state yaitu sebesar Rp 78.468,952/ hari, setelah mengalami kerusakan pertama atau saat mesin sudah beroperasi selama 20 hari tergantung mana yang terlebih dahulu.

Waktu penggantian komponen mesin bagian dalam dapat diketahui dengan menghitung nilai MTTF setiap komponen. Life time komponen bagian dalam mesin dibagi menjadi dua yaitu komponen Bearing dan komponen selain Bearing. Komponen selain Bearing dijadikan menjadi satu data karena jumlah data yang sedikit dan untuk mengetahui pola data life time. Hasil uji distribusi menunjukkan bahwa komponen Bearing dan komponen selain Bearing berdistribusi Weibull. Setelah mengetahui distribusi yang digunakan, maka akan melakukan estimasi parameter. Hasil estimasi parameter didapatkan nilai $\beta$ untuk komponen Bearing sebesar 49,151 dan $\theta$ sebesar 1,063. Komponen selain Bearing mempunyai nilai $\beta$ sebesar 89,216 dan nilai $\theta$ sebesar 0,622 .

Berdasarkan perhitungan MTTF didapat rata-rata kerusakan dari komponen Bearing adalah 48 hari, sehingga dilaku- kan penggantian setelah 2 kali pengecekan dimana jadwal tersebut terjadi lebih dulu sebelum 48 hari. Rata-rata kerusakan komponen selain Bearing adalah 128 hari, sehingga akan dilakukan penggantian setelah 6 kali pengecekan sebelum 128 hari.

\section{KESIMPULAN/RINGKASAN}

A. Kesimpulan

Mesin Dalam Bottomer dilakukan pengecekan setelah kerusakan pertama atau mesin sudah beroperasi selama 20 hari dengan estimasi biaya sebesar Rp 78.468,952/ hari. Penggantian komponen Bearing dilakukan setelah 2 kali pengecekan dimana jadwal tersebut terjadi lebih dulu sebelum 50 hari. Komponen selain Bearing dilakukan penggantian komponen setelah melakukan 6 kali pengecekan dimana jadwal tersebut terjadi lebih dulu sebelum 128 hari.

\section{B. Saran}

Saran yang diberikan berdasarkan hasil analisis dan pembahasan adalah faktor kerusakan hanya disebabkan oleh life time komponen dalam mesin Bottomer, sehingga pada penelitian selanjutnya diharapkan peneliti dapat mencari faktor lain dari kerusakan komponen. Serta melakukan perhitungan pada komponen luar mesin Bottomer untuk pemeliharaan yang dilakukan lebih maksimal. Saran untuk pihak perusahaan adalah pencatatan pada komponen yang rusak harus lebih detail untuk tipe dari komponen yang rusak, sehingga tahu komponen mana yang masuk ke dalam komponen dalam mesin atau komponen luar mesin.

\section{DAFTAR PUSTAKA}

[1] C. Ebeling, An Introduction to Reliability and Maintainability Engineering. Singapore: Mc Graw Hill Book Co., 1997.

[2] F. Leung and A. Cheng, "Determining Replacement Policies for Bus Engines," Int. J. Qual. Reliab. Manag., vol. 17, pp. 771783, 2000.

[3] S. Rigdon and A. Basu, Statistical Methods for the Reliability of Repairable Systems. New York: John Wiley \& Sons, 2000.

[4] N. Tyas, "Penentuan Kebijakan Waktu Optimum Perbaikan Komponen Heat Exchanger (HE) Pesawat Boeing 737-800 Menggunakan Metode Power Law Process di PT. Garuda Maintenance Facility (GMF) Aero Asia," Surabaya, 2016.

[5] E. Hidayati, "Optimasi Penentuan Waktu Penggantian Komponen Impeler pada Mesin Hanger Shot Blast di PT. Barata Indonesia (Persero) Menggunakan Metode Power Law Process (PLP)," Surabaya, 2017.

[6] M. Rausand and A. Hoyland, System Reliability Theory Models, Statistical Methods, and Applications, 2nd ed. New Jersey: John Wiley \& Sons Inc, 2004. 